\title{
Abertura do setor bancário ao capital estrangeiro nos anos 1990: os objetivos e o discurso do governo e dos banqueiros
}

\author{
Carlos Eduardo Carvalho \\ Professor da PUC/SP \\ Carlos Augusto Vidotto \\ Professor da UFF
}

\section{Palauras-chave}

abertura bancária, Brasil, bancos estrangeiros, sistema financeiro brasileiro.

Classificação JEL F23, G21, N26.

Key words

banking sector opening, Brazil, foreign banks, Brazilian financial system.

JEL Classification F23, G21, N26.

\section{Resumo}

A abertura do setor bancário ao capital estrangeiro, em meados dos anos 1990, foi justificada pelo governo como uma iniciativa indispensável para aumentar a concorrência e induzir os bancos brasileiros a baratear e ampliar a oferta de crédito, o que não ocorreu, pelo menos nos anos seguintes. As justificativas do governo, apresentadas de forma lacônica na Exposição de Motivos 311, podem ser tidas como uma cortina de fumaça ou como uma concessão ao discurso liberalizante da época. O objetivo central do governo era outro: estimular o ingresso de capitais externos para o equacionamento das dificuldades do setor bancário com a queda abrupta da inflação e a crise de 1995. O discurso adotado pelos bancos estrangeiros, por seu lado, prometeu mudanças e inovações, "qualidade e preço justo”, mas evitou compromissos com estratégias de atuação diferentes daquelas adotadas pelos grandes bancos brasileiros, que o governo dizia querer reverter com a abertura. $\mathrm{O}$ trabalho analisa o discurso público de ambos e suas contradições com as estratégias de fato seguidas.

\begin{abstract}
The opening up of the Brazilian banking sector to foreign capital in the mid-nineties was justified as essential to promote competition as well as to induce Brazilian banks to increase credit supply and to reduce their costs - which did not happen, at least in that decade. Succinctly presented in the Exposition of Motives 311, such goals can be regarded as a diversionary maneuver or a concession to the contemporary liberal discourse. The main objective of the Government was actually to attract foreign capital in order to cope with banking sector problems caused by a sharp decline in inflation and the effects of the 1995 Mexican crisis. Foreign bankers, in turn, although promising changes and innovations, "quality and fair prices", have avoided any effective commitment to practices different from those commonly used in the Brazilian banking sector. The article analyzes public discourse of both actors and its contradictions with their actual objectives.
\end{abstract}




\section{Introdução}

A forte expansão do capital estrangeiro no segmento bancário de varejo a partir de meados dos anos 1990 representou importante mudança estrutural no setor bancário brasileiro, depois de várias décadas de "reserva de mercado" para o capital nacional e para os bancos públicos. A abertura foi defendida como providência indispensável para ampliar e baratear a oferta de crédito no País, por meio do aumento da concorrência, o que obrigaria os bancos brasileiros a reduzir seus custos e os spreads cobrados e a atender melhor a demanda de empresas e indivíduos.

O resultado da abertura divergiu amplamente do que foi prometido nas declarações oficiais e reforçou a interpretação de que os determinantes da decisão dos estrangeiros de ingressar no Brasil estavam ligados à exploração de oportunidades já oferecidas pela estrutura do mercado brasileiro, diante de dificuldades encontradas para a expansão dos negócios em seus mercados de origem. Essa hipótese é confirmada pela análise do discurso público de seus dirigentes e porta-vozes, em que são evitados cuidadosamente quaisquer compromissos com mudanças nas estratégias operacionais vigentes no País. O governo, por sua vez, priorizava de fato a entrada de capital estrangeiro para equacionar proble- mas enfrentados pelo setor bancário com o Plano Real e a crise de 1995, objetivo mascarado pelas justificativas voltadas para a necessidade de aumentar a "concorrência" e a "eficiência" do sistema.

O objetivo deste trabalho é analisar o discurso adotado pelo governo e pelos banqueiros por ocasião da abertura. Pretende-se explicitar a considerável divergência entre as declarações do governo e os resultados obtidos, bem como a ausência de compromissos claros dos representantes dos bancos estrangeiros com estratégias de atuação diferentes daquelas adotadas pelos grandes bancos brasileiros e que a abertura iria reverter. Espera-se contribuir dessa forma para evidenciar os propósitos efetivamente buscados pelos dois principais atores envolvidos e que foram ocultados pelo discurso público adotado por ambos. A metodologia empregada procura contornar as dificuldades habituais em análises dessa natureza.

O trabalho se estrutura em três seções, além desta introdução e das considerações finais. A primeira seção faz uma breve caracterização do momento em que se deu a abertura, das principais iniciativas adotadas e dos resultados obtidos. Em seguida analisam-se os poucos documentos oficiais disponíveis e procura-se compará-los com as interpretações apresentadas 
no debate acadêmico sobre a estratégia governamental naquele momento. Passa-se então à análise das manifestações dos banqueiros e de seus representantes, por meio de uma amostra de declarações públicas feitas no Brasil e de algumas entrevistas realizadas com sigilo de fonte.

\section{1_ O contexto da abertura e os seus resultados}

Para bancos estrangeiros, os principais fatores de atração de um mercado nacional estão ligados às expectativas de retornos e ao marco regulatório que define o escopo de sua atuação. Sob os dois critérios a atração do mercado de varejo brasileiro fortaleceu-se ao longo dos anos

1 Uma análise minuciosa do sistema bancário brasileiro nos primeiros anos da década de 1990 está em IBGE (1997).

2 Nesse período houve crises bancárias graves na Argentina, na Bolívia, no Chile, na Colômbia, no Equador, no México e no Uruguai (Morris, 1990, p. 70), mas não no Brasil. Além de problemas com instituições pequenas, foram liquidados apenas três bancos de médio e grande porte, em 1985 (Sulbrasileiro, estatizado e reaberto como Banco Meridional; Comind e
1990, com o potencial de expansão dos negócios e a tradição de alta lucratividade associados a uma grande capacidade operacional dos bancos nacionais, em especial dos bancos líderes.

A trajetória do sistema bancário brasileiro durante a alta inflação combinou altos lucros, baixo volume de empréstimos e contínuo desenvolvimento operacional e tecnológico. ${ }^{1}$ A inflação permite aos bancos ganhos elevados, mas também amplia seus riscos, com o aumento da instabilidade macroeconômica e a dificuldade de antecipar os efeitos das medidas adotadas para enfrentá-la. O excelente desempenho foi defendido pelas políticas adotadas para enfrentar a crise do início dos anos 1980, quando o setor público assumiu boa parte da dívida externa e dos custos da crise cambial e se comprometeu a manter a atratividade dos haveres financeiros em moeda nacional (Carvalho, 1992). ${ }^{2}$

A adaptação ao ambiente de alta inflação e instabilidade crônica desenvolveu nos bancos a capacidade de reformular estratégias operacionais com rapidez. Foi o caso das medidas tomadas pelos bancos ao longo do período que antecedeu a entrada do Plano Real, em que se destacou o aumento das operações de crédito em 1992 e em 1993 (Carvalho e Oliveira, 2002), ainda sob inflação elevada. ${ }^{3} \mathrm{O}$ posicionamento dos bancos líderes no setor de varejo tinha 
por objetivo também a defesa de seus espaços de mercado e a imposição de restrições à entrada de outros concorrentes. Embora as barreiras à entrada no setor bancário destacadas em World Bank (1990, p. 31-32) tenham sido as de caráter normativo, sua natureza é mais ampla. Nos últimos anos da inflação alta, os bancos líderes do varejo ofereciam serviços insubstituíveis vinculados à capilaridade de sua rede, aos seus recursos de informatização e às linhas de crédito que podiam operar com base em recursos não remunerados ou captados a taxas menores que as das aplicações. Além disso, os bancos privados bem-sucedidos no segmento de varejo fizeram amplo esforço de redução de custos combinado com grandes investimentos em informatização, que se associaram à eliminação de muitos postos de trabalho. Mesmo o stress bancário de 1995/1996 não reduziu as margens de lucros dos bancos, em boa medida pelo direcionamento de ativos para operações com títulos públicos (Paula, 2000), a fim de compensar os maus resultados das carteiras de crédito. As turbulências da passagem para a inflação baixa ampliaram o mercado potencial para os grandes bancos remanescentes, com a quebra de concorrentes de grande porte e a intervenção federal nos maiores bancos estaduais.

A abertura bancária verificada no Brasil aconteceu com defasagem de mais de meia década em relação à abertura financeira e comercial e só tomou corpo na segunda metade dos anos 1990. De um nível de 9,6\% em 1988, a participação estrangeira nos ativos totais do sistema havia recuado de 9,6\% em 1988 para 7,2\% em 1994, mas em 2000 já alcançava 33,1\%. A expansão da participação de bancos sob controle estrangeiro no setor é um fenômeno recente e decorre do ingresso de novos capitais no sistema: em 2000, dos 71 bancos privados com controle estrangeiro, 29 iniciaram atividades antes de 1988, enquanto os outros 42 tinham menos de 11 anos de atividade no Brasil.

Vista pela participação relativa de cada grupo no patrimônio líquido total do sistema, a expansão do capital estrangeiro está correlacionada ao declínio da participação dos bancos públicos, enquanto os privados nacionais mantiveram sua posição. O processo de expansão, entretanto, deu-se no contexto de intensa disputa entre o capital estrangeiro e o capital privado nacional, como mostra a evolução do patrimônio líquido dos dois grupos a partir de $1996 .^{4}$

$\mathrm{O}$ avanço do capital estrangeiro no mercado bancário de varejo tomou impulso na segunda metade dos anos 1990, atingindo uma participação máxima em 2001 ou 2002, e pode ser avaliado pelo seu impacto no volume e nas condições de oferta de cré-

\author{
4 O "salto" verificado \\ na participação relativa \\ do capital estrangeiro no \\ patrimônio líquido global \\ ocorrido em 1995 , \\ quando atingiu $13,1 \%$ \\ e depois recuado, \\ explica-se pelas quebras \\ (reconhecimento de \\ patrimônio negativo) \\ de alguns grandes bancos \\ privados nacionais, \\ também objeto da \\ Seção 3, e prejuízos \\ (diminuição de \\ patrimônio) de alguns \\ bancos públicos. Vale \\ dizer, não houve o \\ substancial crescimento \\ absoluto que esse \\ percentual pode sugerir.
}


5 Ver BCB (1999), em especial o Gráfico 4, p. 7, que trabalha com uma amostra de 17 bancos. O spread evolui de pouco menos de 3\% a.m. em abril de 1997 para aproximadamente $3,5 \%$ a.m. em junho de 1999 , puxado principalmente pelo crédito dirigido às pessoas físicas.

6 O BCB reconheceu

recentemente que, não obstante as medidas adotadas pelo governo e os

avanços logrados nos últimos seis anos no sentido de facilitar o acesso ao crédito e reduzir o seu custo, o spread bancário permanece elevado (BCB, 2005, p. 9); segundo esse relatório, o spread em junho de 2003 esteve substancialmente mais alto que em junho de 2000 , mesmo nível observado em junho de 2005.

7 Como exemplo dessa percepção, declarou o presidente do Unibanco, Tomas Zinner, à época: "Vemos a concorrência como saudável. Mas os estrangeiros chegaram para ganhar dinheiro, e não vemos nenhum deles atuando de forma muito diferente" (Carvalho, 1997b).

8 Para uma resenha crítica dos estudos empíricos, ver, por exemplo, Souza (2006). dito. Esse avanço não promoveu melhora na relação entre a oferta global de crédito e o nível do PIB (Tabela 1). A evolução das condições de oferta de crédito, por seu turno, pode ser avaliada pelo comportamento das margens brutas de intermediação financeira (spread bancário), historicamente elevadas no Brasil. Após o Plano Real, houve significativo movimento de elevação e a seguir de recuo dos spreads bancários. Entretanto, a partir do segundo trimestre de 1997, quando o grau de abertura bancária ascendera a novo patamar, os spreads voltaram a se ampliar, configurando uma tendência crescente até quase o final da década. ${ }^{5}$ Em razão disso, o Banco Central do Brasil (BCB) lançou amplo programa de medidas de estímulo à redução dos spreads após a desvalorização de 1999. Implicitamente essa decisão atesta a insuficiência da abertura como indutora do rebaixamento das margens e das tarifas, ${ }^{6}$ confirmando a previsão de que haveria um fenômeno de adaptação dos ingressantes estrangeiros ao padrão específico do mercado bancário brasileiro. ${ }^{7} \mathrm{O}$ programa de medidas vem sendo implementado desde então, ao mesmo tempo em que se amplia e se sofistica a literatura que investiga o fenômeno dos spreads persistentemente altos no Brasil. ${ }^{8}$

\section{Gráfico 1_SFN. Evolução do Patrimônio Líquido Total}

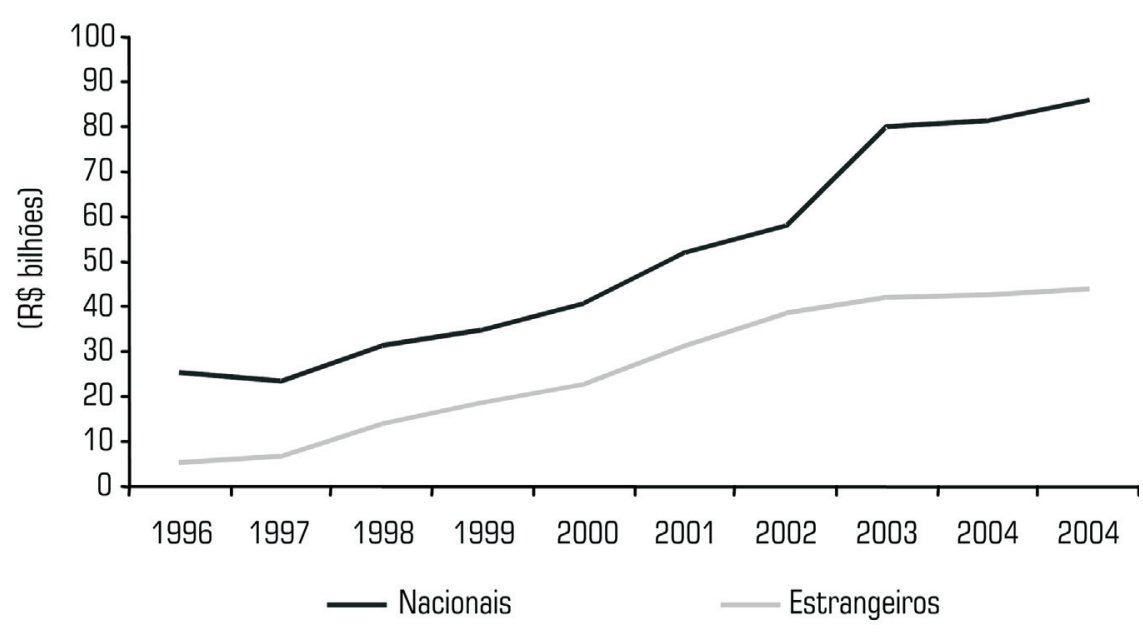

Fonte: Sítio do Banco Central do Brasil. Relatório de Evolulção do Sistema Financeiro. Elaboração própria. 
Tabela 1_SFN. Indicadores da Participação por Controle do Capital

\begin{tabular}{|c|c|c|c|c|c|c|c|c|c|c|c|c|c|c|c|c|}
\hline & \multicolumn{3}{|c|}{ Patrimônio (\%) } & \multicolumn{3}{|c|}{ Depósitos (\%) } & \multicolumn{3}{|c|}{ Crédito (\%) } & \multicolumn{3}{|c|}{$\begin{array}{c}\text { Crédito (\%)/ } \\
\text { Patrimonio (\%) }\end{array}$} & \multicolumn{3}{|c|}{$\begin{array}{c}\text { Crédito (\%)/ } \\
\text { Depósitos (\%) }\end{array}$} & \multirow{2}{*}{$\begin{array}{c}\text { Crédito/ } \\
\text { PIB }\end{array}$} \\
\hline & Estr & Pr.Nc & Pub & Estr & Pr.Nc & Pub & Estr & Pr.Nc & Pub & Estr & Pr.Nc & Pub & Estr & Pr.Nc & Pub & \\
\hline 1993 & 7,3 & 48,2 & 44,0 & 4,8 & 38,8 & 56,3 & 6,6 & 31,5 & 61,8 & 0,90 & 0,65 & 1,40 & 1,36 & 0,81 & 1,10 & 29,0 \\
\hline 1994 & 9,6 & 55,6 & 34,1 & 4,6 & 39,4 & 55,9 & 5,2 & 35,4 & 59,1 & 0,54 & 0,64 & 1,72 & 1,13 & 0,90 & 1,06 & 36,6 \\
\hline 1995 & 13,1 & 49,2 & 36,3 & 5,4 & 36,4 & 58,0 & 5,7 & 31,8 & 62,1 & 0,44 & 0,65 & 1,71 & 1,06 & 0,87 & 1,07 & 35,0 \\
\hline 1996 & 11,4 & 54,2 & 33,1 & 7,2 & 33,4 & 59,2 & 9,5 & 31,9 & 58,1 & 0,83 & 0,59 & 1,75 & 1,33 & 0,96 & 0,98 & 31,2 \\
\hline 1997 & 14,3 & 51,8 & 32,3 & 7,5 & 32,9 & 59,1 & 11,7 & 35,4 & 52,2 & 0,82 & 0,68 & 1,61 & 1,55 & 1,08 & 0,88 & 28,9 \\
\hline 1998 & 21,9 & 49,8 & 26,8 & 15,1 & 33,1 & 51,2 & 14,9 & 31,0 & 53,2 & 0,68 & 0,62 & 1,99 & 0,98 & 0,94 & 1,04 & 29,9 \\
\hline 1999 & 25,5 & 46,7 & 26,1 & 16,8 & 31,8 & 50,6 & 19,8 & 31,7 & 47,5 & 0,78 & 0,68 & 1,82 & 1,18 & 0,99 & 0,94 & 27,2 \\
\hline 2000 & 28,3 & 50,3 & 19,4 & 21,1 & 33,9 & 43,9 & 25,2 & 34,5 & 39,1 & 0,89 & 0,69 & 2,02 & 1,19 & 1,02 & 0,89 & 28,3 \\
\hline 2001 & 30,7 & 51,1 & 16,1 & 20,1 & 35,3 & 43,2 & 31,5 & 42,1 & 24,8 & 1,03 & 0,82 & 1,54 & 1,56 & 1,19 & 0,57 & 26,8 \\
\hline 2002 & 32,9 & 48,7 & 16,3 & 19,8 & 36,6 & 42,1 & 29,9 & 39,7 & 28,6 & 0,91 & 0,82 & 1,75 & 1,51 & 1,09 & 0,68 & 24,2 \\
\hline 2003 & 28,1 & 53,2 & 16,5 & 17,6 & 38,2 & 42,4 & 23,8 & 41,3 & 32,7 & 0,85 & 0,78 & 1,98 & 1,36 & 1,08 & 0,77 & 26,2 \\
\hline 2004 & 27,1 & 52,9 & 17,5 & 19,9 & 39,4 & 39,3 & 25,1 & 41,3 & 31,3 & 0,93 & 0,78 & 1,79 & 1,26 & 1,05 & 0,80 & 26,9 \\
\hline 2005 & 24,6 & 54,2 & 18,4 & 20,3 & 41,6 & 36,8 & 26,4 & 40,8 & 30,5 & 1,07 & 0,75 & 1,66 & 1,30 & 0,98 & 0,83 & 31,2 \\
\hline
\end{tabular}

Estr $=$ Estrangeiro

$\operatorname{Pr} . \mathrm{Nc}=$ Privado Nacional

Pub $=$ Público

Fonte: Sítio do Banco Central do Brasil (Relatório de Evolução do Sistema Financeiro).

Até 1995: Relatório de 1998; de 1996 a 2005: Relatório de 2005;

Relação Credito/PIB: Sitio do Bacen, Séries Temporais. Acesso em 14/03/2007.

Elaboração dos autores. 


\section{2_Mudanças regulatórias e objetivos do governo}

\section{1_ Restrições aos bancos estrangeiros no varejo bancário brasileiro}

A distinção entre instituições financeiras nacionais e estrangeiras apareceu na Constituição de 1934 e foi reforçada na de 1937, que determinava a "nacionalização" dos bancos não controlados por cidadãos brasileiros (Morais, 1990). Com sucessivas concessões, a presença dos bancos estrangeiros permaneceu próxima do que existia antes da crise de 1929, quando muitos deles reduziram as operações no País. A Constituição de 1945 remeteu o assunto à legislação ordinária. Em 1962, no governo Goulart, a Lei n. 4.131 disciplinou a participação do capital estrangeiro na economia brasileira e as remessas de lucros ao exterior e condicionou a operação dos bancos estrangeiros ao princípio da reciprocidade: um banco estrangeiro deveria receber tratamento similar ao dispensado a bancos brasileiros em seu país de origem. A reforma bancária da ditadura militar, no final de 1964, abrigou esse princípio em seu texto. ${ }^{9}$

Contudo, como parte da abertura financeira parcial promovida pela Resolução 63, de 1967, o segundo governo da ditadura permitiu o aumento da participação externa no capital dos conglomerados financeiros brasileiros, sem alterar as restrições "de fato" à ampliação de sua atividade no varejo. ${ }^{10}$ Anos depois, na tentativa de impulsionar o mercado de capitais, adotou-se por via administrativa um limite aos não residentes de $33 \%$ do capital com direito a voto nos bancos de investimento, financeiras e outras instituições vinculadas a esse mercado. Ao longo da década de 1980, essas mudanças favoreceram dois movimentos conexos: o endividamento externo e o aumento no grau de internacionalização do sistema bancário, simultaneamente à promoção da concentração e da conglomeração bancária. ${ }^{11}$

A liberalização bancária promovida pelo BCB a partir de 1988 acentuou em termos relativos a diferença de tratamento regulatório por origem de capital, uma vez que as oportunidades criadas eram seletivas. A nova Constituição Federal renovou as disposições restritivas à expansão do capital estrangeiro, e as medidas então adotadas permitiram a expansão e a diversificação do capital nacional no mercado bancário. ${ }^{12} \mathrm{~A}$ Constituição previa que lei complementar ordenasse o sistema financeiro, dispondo sobre as condições para a participação do capital estrangeiro nas instituições financeiras tendo em vista os interesses nacionais e os acordos internacionais (art. 192, inciso III), mas o Ato das 
Disposições Constitucionais Transitórias proibiu a instalação de novas agências e o aumento de participação de não-residentes no capital das instituições existentes, exceto quando autorizado em acordos internacionais, de reciprocidade, ou de interesse do governo brasileiro (art. 52 do ADCT).

Embora a abertura comercial e financeira tenham se acelerado a partir de 1990, o quadro restritivo permaneceu inalterado. ${ }^{13}$ Mesmo um pouco antes do lançamento do real, quando incorporou os requerimentos associados ao "Acordo de Basiléia" ao quadro normativo brasileiro, o $\mathrm{BCB}$ reiterou o congelamento do capital estrangeiro nos níveis vigentes em $1988 .{ }^{14}$ A exigência de níveis de capitalização bem mais elevados para bancos de origem es- trangeira, por não ser coerente com os princípios daquele Acordo, sugere que a autoridade reguladora ainda não havia amadurecido uma diretriz pró-abertura do setor bancário. Essa hipótese torna-se ainda mais verossímil ao se levar em conta a suposição do BCB quanto à vantagem competitiva (de capital, tecnológica e operacional) dos estrangeiros, como se verá mais adiante.

A situação só começou a se alterar no início do governo Cardoso, em 1995, quando se tornou conhecida a existência de um conflito intragovernamental relativo à proteção do setor bancário, com indícios relevantes de que o $\mathrm{BC}$ e o Ministério da Fazenda defendiam o ingresso seletivo do capital estrangeiro para viabilizar a privatização dos bancos estaduais. ${ }^{15} \mathrm{Um}$ forte in-

\footnotetext{
13 Diversos grupos estrangeiros, 14 A Res. 2099 estabeleceu

já presentes no mercado brasileiro, reposicionaram-se ou constituíram um banco múltiplo por meio de expedientes diversos - transferência da participação de outros bancos estrangeiros, recuperação de autorizações concedidas antes de 1988 (retroagindo até as expropriações da época da Segunda Guerra Mundial, para o capital japonês e alemão). O impacto dessas iniciativas foi praticamente irrelevante no conjunto do mercado.

14 A Res. 2099 estabeleceu
que as instituições estrangeiras
deveriam apresentar nível de
capitalização equivalente ao
dobro das instituições
nacionais (art. $1^{\circ}, \int 3^{\circ}$,
do Reg. Anexo II). O art. $9^{\circ}$
da mesma Resolução reafirma
a posição de 1988 em termos
de capital e o art. 17
condiciona expansão da rede à
regulamentação do art. 192 da
Constituição Federal.
15 “ A Folha apurou que a quebra
da reserva de mercado para os bancos
nacionais divide o governo. A saída

encontrada pelos ministros que conduzem a reforma foi adiar o envio de emendas sobre o sistema financeiro. Enquanto o ministro do Planejamento, José Serra, prefere estudar melhor a oportunidade de abrir o mercado, o Banco Central e o Ministério da Fazenda defendem a entrada de capital estrangeiro para tornar viável o processo de privatização dos bancos estaduais." (Folha de S. Paulo, 22/2/1995). A restrição da entrada à compra dos estaduais voltou ao noticiário em 1997, depois da compra do Bamerindus pelo
}

\section{HSBC: "O BC não deverá}

autorizar novas participações estrangeiras em bancos de varejo no Brasil porque avalia que as instituições nacionais em operação estão, nesse momento, em boa situação. A informação foi dada ontem, no Rio, pelo diretor de Normas Sérgio Dary. Ele explicou que, a partir de agora, a única porta de entrada no varejo será através da privatização dos bancos estaduais." (Velloso, 1997b). 
$\because \ldots \ldots \ldots \ldots$

16 Em 1995 foram abertos, por meio de PEC específicas, os setores de navegação de cabotagem e telecomunicações, além da quebra do monopólio da exploração de petróleo pela Petrobras.

17 Por exemplo, mesmo afirmando que, "verificada a incapacidade das instituições financeiras nacionais em arcar com os encargos dos respectivos processos de atualização tecnológica e de crescimento, com suporte exclusivo na poupança interna, imprescindível se torna o reforço de suas estruturas de capital, via participação de recursos do exterior", a EM não condiciona a abertura à transferência de controle de instituições.

18 Para uma discussão nesse sentido, ver Vidotto (1999).

19 O Banco Econômico já apresentava dificuldades consideráveis desde pelos menos alguns meses antes da intervenção do BCB, a exemplo do que ocorreria em seguida com o Nacional e com o Bamerindus (Carvalho e Oliveira, 2001). dício de que a visão pró-abertura ainda não era dominante no governo apareceu ao início da gestão FHC, quando o Poder Executivo encaminhou diversos Projetos de Emendas Constitucionais (PEC) de caráter liberalizante ao Congresso Nacional. Uma das principais emendas suprimiu a distinção entre empresa de capital nacional e estrangeiro, ${ }^{16}$ mas o setor financeiro foi excluído dessa uniformização de tratamento em razão da restrição presente nas disposições transitórias da Constituição, mencionada há pouco.

\subsection{Os reais motivos de uma Exposição de Motivos}

O registro mais importante (e único, ao que se sabe) das motivações do governo para a abertura do setor bancário é a Exposição de Motivos no 311 - EM 311, de 24/8/1995, em que o ministro da Fazenda propõe ao presidente da República que utilize as prerrogativas constitucionais "para reconhecer como de interesse do Governo brasileiro a participação ou o aumento do percentual de participação de pessoas físicas ou jurídicas, residentes ou domiciliadas no exterior, no capital de instituições financeiras nacionais". A redação sugere fortemente que a EM 311 não fazia a defesa de uma abertura ampla e generalizada do setor bancário, mas sim de um aumento da participação do capital estrangeiro, ${ }^{17}$ com base em um conjunto de contribuições esperadas, expostas em seguida. Acrescente-se que a EM 311 não foi acompanhada por autorização de ingresso de algum banco estrangeiro. ${ }^{18}$

O momento da edição da EM 311 era bastante delicado. Semanas antes, no início de agosto, o governo decidira enfim liquidar o Banco Econômico, o primeiro dos grandes bancos privados a quebrar na seqüência do Plano Real. ${ }^{19}$ A liquidação do Econômico vinha sendo postergada havia meses, dado o risco de deterioração das expectativas sobre a economia brasileira em meio às ondas de choque detonadas pela crise mexicana de dezembro anterior. É possível afirmar que todo o discurso sobre a situação do setor bancário brasileiro estivesse de fato encobrindo o receio de fragilização generalizada do sistema, a exemplo do que ocorria na Argentina e no México naquele momento.

As justificativas apresentadas pela EM 311 combinam questões referentes aos bancos brasileiros e a suas formas de atuação, em especial as condições patrimoniais e as formas de concorrência do setor, com a reiteração de orientações gerais da política econômica do período em termos de abertura externa e captação de recursos para financiar o balanço de pagamentos. 
O diagnóstico inicial apresentado pela EM 311 é de que as instituições financeiras brasileiras eram "ineficientes administrativamente" e compensavam sua fragilidade com ganhos permitidos pela inflação alta. Assim, no contexto de baixa inflação, a fragilização dos bancos nacionais teria evidenciado a "escassez de capitais nacionais". Esses capitais seriam necessários para manter o "contínuo processo de atualização tecnológica, típico das instituições financeiras competitivas, que lhes assegura melhor remuneração ao poupador e menor custo ao tomador de crédito mediante redução da margem de intermediação".

No nível microeconômico, a presença estrangeira aumentaria a solidez e a eficiência do setor bancário por meio da capitalização e modernização técnica das instituições. Nesse mesmo nível resultariam - justamente o non sequitur em questão - menores custos dos serviços. A solução no nível microeconômico proporcionaria também ao sistema financeiro, agora no plano macroeconômico, maior eficiência alocativa da poupança nacional, além de atenuar as dificuldades do setor externo.

$\mathrm{Na}$ concepção exposta na EM 311, os fatores microeconômicos têm precedência, pois é a partir deles que se vislumbram efeitos positivos para o conjunto da economia, talvez dominantes no processo decisório dos policy makers do Plano Real. ${ }^{20}$
Não é de estranhar a precedência lógica microeconômica, diante da afinidade teórica implícita do texto com o individualismo metodológico e com o conceito convencional de concorrência, cuja referência é a proximidade ou o afastamento do modelo de mercado perfeitamente competitivo. Daí, portanto, surgem dois pontos prioritários no nível microeconômico para uma breve discussão: a transferência dos ganhos de eficiência aos consumidores e a solidez proporcionada pelo ingresso do capital estrangeiro.

Para a EM, a maior presença dos estrangeiros seria positiva por implicar "maior concorrência", sem mencionar mudanças nas formas de concorrência, como se "concorrência" fosse algo genérico, abstrato, cujo "aumento" se traduziria necessariamente em melhores preços de serviços e em queda dos juros. ${ }^{21} \mathrm{~A}$ hipótese subjacente à previsão de que haveria uma queda no custo dos serviços bancários e nas taxas de juros aos tomadores de crédito corresponde, mais amplamente, à concepção de um setor bancário dominado por mecanismos concorrenciais que o aproximam de um mercado competitivo onde o preço, isto é, taxas de juros e tarifas de serviços, operasse como sinalizador para o comportamento da demanda.

Pesquisas recentes não apresentam resultados conclusivos. Um estudo do BCB encontrou que o sistema bancário brasilei- $\cdots \cdots \cdots$

20 Afirma o documento que a abertura "não somente resultará em reforço financeiro para o país, representado pela captação de poupança externa e acréscimo nas reservas internacionais, mas, sobretudo, em ganhos econômicos decorrentes da introdução de novas tecnologias de gerenciamento de recursos e inovações de produtos e serviços, possibilitando maior eficiência alocativa da economia brasileira" (grifo dos autores).

21 Essa visão tem amplo trânsito nos órgãos formadores de opinião. O editorial da Gazeta Mercantil que apoiou a EM 311 (29/8/1995, p. A4) defendeu que "o capital estrangeiro poderá dar uma contribuição inestimável nessa fase para o revigoramento do sistema bancário nacional"'. $\mathrm{Na}$ seqüência, o editorial citou o caso do Econômico, e também o dos bancos estaduais sob intervenção e em dificuldades, e propôs no fim que o aumento da participação do capital estrangeiro se estendesse a todos os segmentos do SFN, "de modo a elevar o seu nível de eficiência e proporcionar melhores serviços à comunidade brasileira". 
ro não se situa no extremo da perfeita competição nem no do oligopólio, apontando que a aproximação ao padrão competitivo tem grande grau de aderência nos segmentos de atacado (Nakane, 2003), mas a novidade do fenômeno da abertura bancária após a estabilização está justamente nos segmentos de varejo. Outro trabalho, do FMI, afirma que bancos brasileiros comportam-se oligopolicamente (Belaisch, 2003). Se a análise apoiar-se numa visão não ortodoxa do processo de concorrência que identifique a margem bruta de lucro como variável síntese de uma estrutura de mercado (por exemplo, Possas, 1984), a conclusão vai alinhar-se com este último estudo.

O diagnóstico da ineficiência e carência de capitais nativos, ao lado da concepção convencional da concorrência bancária, complementa-se por fim com a hipótese de que os bancos estrangeiros teriam maior qualificação que os nacionais em recursos tecnológicos e em eficiência operacional. A EM 311 aponta a expectativa de "ganhos econômicos decorrentes da introdução de novas tecnologias de gerenciamento de recursos e inovações de produtos e serviços, permitindo maior eficiência alocativa", posto que os capitais externos têm "eficiência operacional e capacidade financeira" que trariam maior concorrência ao sistema financeiro, "com reflexos substancialmente positivos nos preços dos serviços e no custo dos recursos oferecidos à sociedade brasileira".

É plausível que as corporações financeiras dos países centrais detivessem um acervo de tecnologia bancária para as condições de prolongada estabilidade macroeconômica, mas havia outros fatores a considerar: conhecimento do país, experiência com os clientes, adaptação aos riscos de instabilidade macroeconômica, etc. Vale lembrar que todos os bancos estrangeiros adotaram a estratégia de aquisições, herdando culturas, sistemas e outras condições cuja reciclagem consumiria tempo e energia empresarial. O crescimento orgânico, em que a maior experiência das matrizes poderia ser decisiva, não foi empreendido nem mesmo pelos bancos que já tinham forte presença no Brasil.

Em conclusão, vista de conjunto e em perspectiva histórica, a tese da superioridade competitiva dos estrangeiros não retém validade geral e não resistiu à retirada de alguns players globais do mercado de varejo brasileiro ocorrida na década atual, como o BBV. À época do lançamento da EM 311, sua sustentação no discurso oficial se coadunava com o esforço de apresentar a abertura bancária como veículo de benefício econômico geral.

Uma segunda ordem de questões presentes na EM 311 é a de que a expansão do capital estrangeiro significaria maior so- 
lidez das instituições locais e do sistema bancário em conjunto, já que a subsidiária ou filial contaria com o respaldo permanente da matriz, com efeitos positivos para a solidez do setor bancário em economias periféricas. ${ }^{22}$ Num raciocínio estático, é quase tautológico afirmar que a abertura bancária fortalece o sistema toda vez que o capital estrangeiro toma o controle de uma instituição fragilizada. ${ }^{23}$ Só que o mesmo ocorreria com estatização ou aquisição pelo capital nacional, com apoio estatal ou sem ele. Cabe acrescentar também que cada uma dessas possibilidades coloca problemas específicos em graus também específicos: perda de controle nacional, questões fiscais e regulatórias, ou risco de contágio, respectivamente.

O efeito sobre o sistema que pode ser atribuído exclusivamente à abertura depende das circunstâncias próprias a cada experiência. Como no caso brasileiro, o capital estrangeiro dirigiu-se prioritariamente a bancos em dificuldades, e durante um período de stress, é lógico afirmar que houve uma contribuição ao saneamento e fortalecimento do sistema once and for all. Contudo, quando voltou a instabilidade externa, a maior presença de bancos estrangeiros não deteve a crise cambial de 1998/1999 e não impediu o estancamento das linhas externas nas crises de 2001 e 2002. Também não é possível afirmar de modo inquestionável que nessas duas últimas crises o sistema bancário não enfrentou maiores dificuldades porque estivesse mais sólido devido ao Proer e à abertura ao capital estrangeiro. Ao contrário, pode-se sustentar que o fator decisivo para a não-fragilização bancária nesses dois momentos foi a assunção prévia dos prejuízos pelo Tesouro (com a emissão de títulos com correção cambial em 1998) e a elevação imediata da carga tributária para absorver a forte elevação da dívida pública e os custos de sua rolagem no mercado doméstico, além da mu-

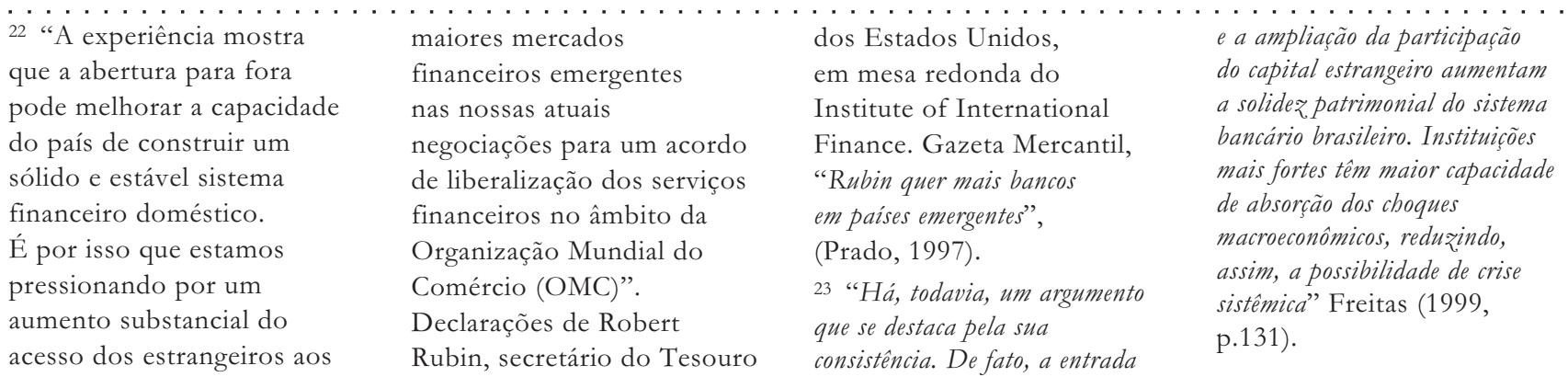


24 A taxa básica de juros nas crises de 2001 e 2002 mal ultrapassou a metade do nível a que foram elevadas nas crises de 1995, 1997 e 1998 o que reduz em muito o impacto indireto (via fragilização da clientela e da carteira de crédito) e direto da instabilidade externa sobre o setor bancário. dança no regime cambial que permitiu a prática de juros nominais bem menores em momentos de instabilidade externa. ${ }^{24}$

A rigor, não há qualquer garantia de que filiais de bancos estrangeiros exerçam papel decisivo em situações de crise. Segundo um estudo do FMI que analisou a experiência recente dos bancos estrangeiros em países da América Latina, Ásia e Europa Oriental, variaram muito as atitudes deles em situações de crise nos países dependentes em que atuam suas filiais, incluindo desde a cobertura de perdas e a ampliação da oferta de recursos, de um lado, até o corte do crédito e a retirada abrupta, de outro (Mathieson e Schinasi, 2001). A conclusão do estudo é bastante clara:

Até agora, são limitadas as evidências sobre a contribuição da presença de bancos estrangeiros para a estabilidade do sistema bancário e da oferta de crédito (Mathieson e Schinasi, 2001).

Além dos temas acima, a EM 311 incorpora num segundo bloco expositivo as orientações gerais da política econômica do período em termos de abertura externa e de captação de recursos para manter o financiamento do balanço de pagamentos. Além da preocupação com o equilíbrio externo, presente em todo período, deve-se considerar o delicado momento vivido após a decisão de liquidar o Banco Econômico, quando o documento foi dado a público.

Enfim, os efeitos positivos da abertura bancária com que acenava a EM 311 decorriam de uma combinação dos atributos do capital estrangeiro e das características do mercado bancário. A solução no nível microeconômico (solidez e eficiência microeconômicas) viabilizada pelo ingresso do capital estrangeiro induziria a prática de margens de intermediação menores pelos bancos e a obtenção de benefícios macroeconômicos - maior eficiência alocativa da poupança nacional e menor restrição externa.

A idéia da superioridade competitiva do capital estrangeiro exercendo seu potencial transformador no mercado doméstico correspondia ao entendimento de que os estrangeiros viriam para cumprir essa missão. Entretanto, para que essa missão não fosse cumprida, bastaria que o mercado não fosse concorrencial e/ou que a alegada superioridade dos bancos estrangeiros (de capital, tecnológica e operacional) fosse insuficiente para ameaçar os grandes bancos nacionais, além da possibilidade de que a missão não correspondesse às opções estratégicas do capital estrangeiro, como discutido na seção 3 . 


\section{3_ 0 processo de abertura}

Após o lançamento do Plano Real, o impacto da queda da inflação sobre as receitas e a presença de alguns grandes bancos com problemas estruturais, assim como a política monetária restritiva depois da crise do México, colocaram a possibilidade de uma crise bancária. A junção desse contexto com a relutância do capital estrangeiro inviabilizou a estratégia de condicionar seu ingresso à privatização de bancos estaduais. Em 1995 as autorizações ao capital estrangeiro foram esporádicas e pouco expressivas, limitadas à compra de bancos quebrados. ${ }^{25} \mathrm{Nem} \mathrm{a}$ limitação da alavancagem de um novo banco a três vezes seu patrimônio no pri- meiro ano de funcionamento (Resolução n. 2.212, de novembro de 1995), dificultando que o ingressante optasse por crescimento orgânico, convenceu o capital estrangeiro a lançar-se no mercado de varejo pela aquisição de um banco público.

A EM 311 surgiu logo após a intervenção no Banco Econômico, primeiro dos grandes bancos a quebrar, ${ }^{26}$ sem associação com nenhuma autorização específica de ingresso. Àquela altura, o discurso oficial sobre falta de recursos dos bancos brasileiros compatibilizava-se com o receio de fragilização generalizada do sistema, como no México e na Argentina. Dois meses depois o Banco Nacional entrou em colapso, ${ }^{27}$ e o BCB suspendeu a exi-
${ }_{25}$ De acordo com

informações do próprio

Banco Central, entre 1\%/7/1994 e 18/4/1996, 63 instituições financeiras foram submetidas ao RAER (Regime de Administração Especial

Temporária), entre as quais 24 bancos múltiplos, três bancos comerciais, um banco de investimento, um banco estadual de investimento, duas sociedades de arrendamento mercantil, 12 corretoras, 15 distribuidoras e uma sociedade de crédito imobiliário. Em relação aos regimes especiais,

42 instituições foram liquidadas extrajudicialmente, 13 ficaram sob administração temporária, uma teve sua falência decretada e sete sofreram intervenção.

26 A liquidação do Banco Econômico vinha sendo postergada havia meses, dado o risco de deterioração das expectativas sobre a economia brasileira em meio às ondas de choque detonadas pela crise mexicana de dezembro de 1994. Para uma análise desse episódio e da posterior quebra do Banco Nacional e do Bamerindus, ver Carvalho e Oliveira (2002) e Carvalho (1996).

27 Em novembro de 1995 , junto com a intervenção no Banco Nacional, foi criado o Programa de Estímulo à

Reestruturação e

Fortalecimento do Sistema Financeiro (PROER), por meio do qual o BCB ficou autorizado a disponibilizar recursos para que instituições financeiras sólidas adquirissem o controle acionário de bancos em dificuldades (Medida Provisória n. 1.179, depois Lei n. 9.710/98, e Resolução CMN n. 2.208, com data retroativa da véspera, 3/11/1995). A liquidação do Banco Nacional foi feita sob a legislação do PROER; o Banco Econômico, liquidado em agosto anterior, também foi "vendido", sob o regime do PROER, em abril de 1996. O Proer é analisado em Vidotto (2005). 
gência de capital mínimo diferenciado para bancos estrangeiros. ${ }^{28}$ Além disso o CMN ampliou o espaço de negociação de ações de bancos brasileiros (sem direito a voto) pelo capital estrangeiro. ${ }^{29}$ A partir de 1996, o governo aumentou a freqüência das autorizações para ingresso ou expansão de instituição estrangeira, e o BCB impôs a candidatos estrangeiros a assunção de "rombos" (desequilíbrio entre passivos e ativos) de instituições sob intervenção ou em regime especial - caso dos grandes bancos estaduais - ou em liquidação. ${ }^{30}$ Entretanto, esses movimentos ainda eram pouco expressivos.
O quadro de restrição à entrada do capital estrangeiro no mercado bancário de varejo rompeu-se, de fato, no primeiro semestre de 1997. Inicialmente houve a compra do Banco Geral do Comércio (BGC) pelo Santander, de capital espanhol. ${ }^{31}$ Essa operação envolveu uma instituição fora da arena principal da concorrência bancária e limitada como plataforma de crescimento orgânico. A aquisição do Banco Multiplic e da Financeira Losango pelo Banco Lloyds (inglês), visando substituir a logística baseada em agências pelo telemarketing, também teve caráter experimental. $\mathrm{O}$ verdadeiro divisor de águas

do CMN, de $20 / 11 / 95$,
parte das medidas que
prepararam o Proer, o BC
eliminou a diferenciação de
capital mínimo entre
instituições nacionais e
estrangeiras da Res. 2.099 .
Também permitiu que filiais
de bancos estrangeiros (não
apenas subsidiárias)
constituíssem banco múltiplo,
mas eliminou da legislação
possibilidade de instituição
externa criar mais de um
banco múltiplo.
29 A Resolução n. 2.344
abriu, para fundos, sociedades
e carteiras Anexos I a IV

28 Com a Res. 2.212

da Res. n. 1.289/87, a possibilidade de aplicar em ações sem direito a voto de instituições financeiras com sede no País.

A Resolução n. 2.345 autorizou o lançamento de programas ADR (Anexo V) com lastro em ações sem direito a voto de instituições com sede no País. Assim o Unibanco pagou os ativos absorvidos com ações preferenciais que ficaram em poder do BCB, cuja venda, parte no exterior e parte no mercado doméstico, alcançou US $\$ 1,228$ bilhão (Carvalho, 1997a).

30 Uma lista informal de
"pedágios" e ingressantes foi
batizada de "tabela Moura",
em alusão ao diretor do BCB
Alkimar Moura. A exclusão do
pedágio referia-se ao
Mercosul, à privatização de
bancos estaduais e episódios
de interesse específico,
como o ingresso do Korean
Exchange Bank, mais adiante,
ou quando a própria aquisição
de controle já implica
gastos expressivos de limpeza
de ativos, como a compra
pela Volvo do Transbanco
de Investimentos, para
conversão em múltiplo
(Carvalho, Alves e Bortot,
1996). Por esse caminho ingressaram inicialmente o Banque Nationale de Paris (BNP), o Banco Ford e o Deutsche-Südamerikanische Bank (DSB).

31 O Banco Santander adquiriu $55 \%$ do controle do BGC, do grupo Camargo Correa, que se tornou Santander Brasil e, por meio deste último, adquiriu nesse mesmo ano o controle do Banco Noroeste. Sobre a estratégia dos bancos espanhóis na América Latina, ver Calderón e Casilda (2000). 
foi o desfecho dado à crise do Banco Bamerindus, cuja "parte boa" foi transferida ao HSBC em março. O fato de o ex-controlador do banco ser um líder da base parlamentar governista fortaleceu a imagem da autoridade monetária como condutora da abertura; além disso, como a transação ocorreu ao amparo do Proer, o setor público assumiu-se como seu financiador e garantidor (Vidotto, 2005).

Depois da transferência do Bamerindus ao $\mathrm{HSBC}$, o $\mathrm{BCB}$ tentou retomar a estratégia de condicionar o ingresso dos competidores externos à aquisição de bancos estaduais, ao exigir que as transações fossem precedidas de consulta formal, o que permitiria induzir o direcionamento de- sejado. ${ }^{32}$ Essa pretensão discricionária foi afirmada pelo ministro da Fazenda ${ }^{33}$ e novamente explicitada no final do ano. ${ }^{34}$ Além de direcionar o mercado de aquisições bancárias, o governo brasileiro reagia às pressões por ampla abertura bancária e financeira então preconizada pelas autoridades dos governos centrais e instituições multilaterais.

O fracasso de tal estratégia materializou-se em 1998, ao consolidar-se o ingresso do capital estrangeiro via aquisição de instituições privadas. No início do ano, a Caixa Geral de Depósitos, controlada pelo Tesouro português, adquiriu o controle do Banco Bandeirantes..$^{35}$ Em abril o Banco Bilbao-Viscaya, espanhol, assumiu o controle do Excel Econômico. ${ }^{36}$ Além desses

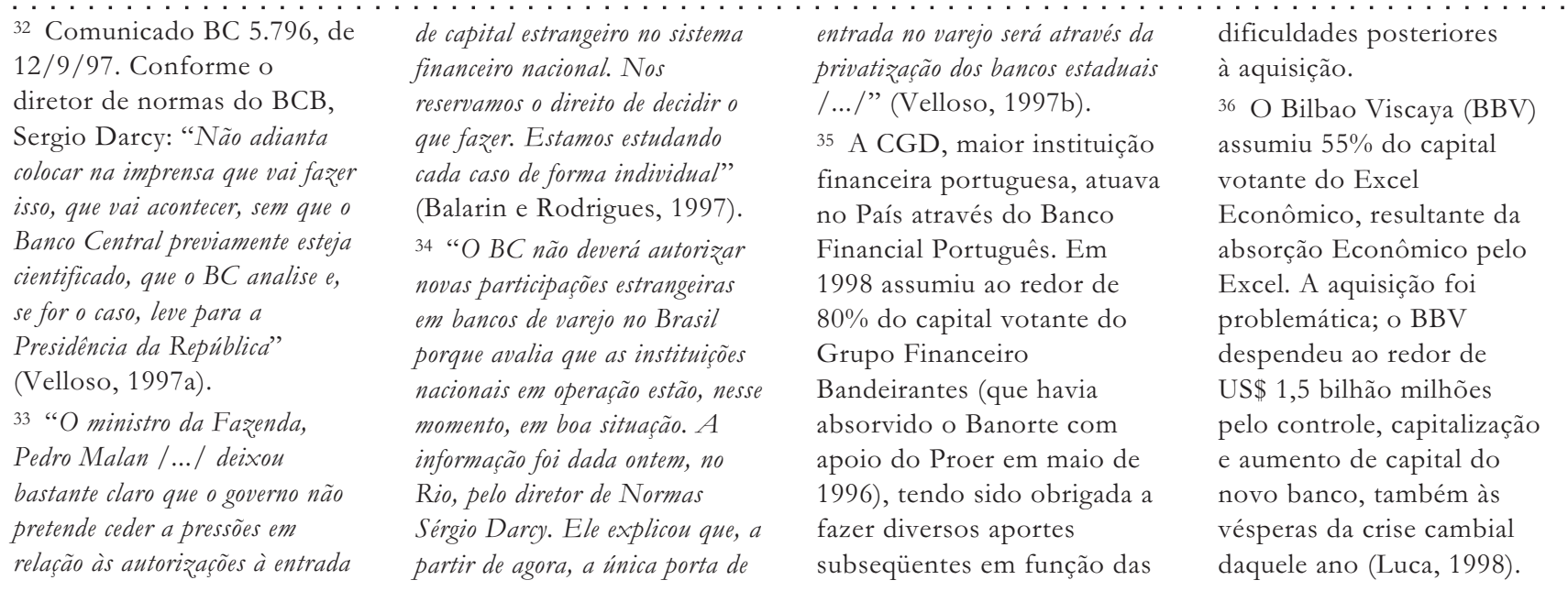


episódios, o Grupo Espírito Santo, português, assumiu o controle do Banco Boa Vista ${ }^{37}$ e o Sudaméris adquiriu o América do Sul. ${ }^{38} \mathrm{O}$ caso limite de reestruturação via mercado foi a transferência do controle do conglomerado Real para o ABN-Amro Bank, em íntima conexão com a resposta do governo à crise cambial. ${ }^{39}$ Em contraste com a estratégia do $\mathrm{BCB}$, os bancos estaduais foram comprados prioritariamente pelo capital privado nacional; com a exceção da vitória do Santander no leilão do Banespa, ao final de 2000 - mas então o momento de maior fragilidade do sistema bancário nacional já havia sido superado. ${ }^{40}$

Dois outros aspectos de todo esse processo merecem ênfase. Primeiro, a abertura ao capital estrangeiro foi além do segmento de varejo. No triênio 1996-1998 quase duas dezenas de bancos com perfil atacadista ingressaram, expandiram-se ou se associaram no mercado brasileiro. Essa presença, combinada com os efeitos da crise cambial, reduziu as receitas nesse mercado (comissões de operações, taxas de consultoria de fusões, aquisições, privatizações e gestão de recursos), dificultando a sobrevivência de instituições de capital nacional. Assim, em 1998 o Crédit Suisse First Boston (CSFB) absorveu o Banco Garantia e, em janeiro de 2000, a área financeira do grupo Bozano, Simonsen foi vendida para o Santander, incluindo o controle do banco Meridional (banco federal privatizado e de presença na região Sul).

O outro destaque foi o movimento de renacionalização do sistema bancário. Já em 2001 o Unibanco assumiu o controle
37 O Boa Vista já vinham de uma trajetória de forte deterioração. A composição acionária dos novos controladores envolvia além do GES, o Grupo Monteiro Aranha, o Crèdit Agricole, o Bradesco e o Dresdner.

38 Com a aquisição, o Banco Sudaméris, indiretamente controlado pela Banca Commerciale Italiana, praticamente igualou-se ao HSBC Bamerindus em ativos, com rede muito menor. Mesmo sem apresentar prejuízo, o América do Sul, controlado pela Fundação América do Sul e Fuji Bank, do Japão, acusava aumento dos créditos problemáticos.

39 A operação envolveu "pedágio" recorde de $\mathrm{R} \$ 200$ milhões e a aquisição do Banco do Estado de Pernambuco, em 17/11, incluindo conjunto expressivo de benefícios ao comprador.
"A entrada dos US\$ 2,1 bilhões
ficou com o braço
do preço pago pelo ABN-Amro ajudou o Banco Central a administrar as expectativas em um momento delicado de perda de reservas internacionais. Segundo Oyevaar, vice-presidente executivo sênior do $A B N$-Amro, o governo brasileiro pediu ao ABN-Amro para acelerar o pagamento, o que fezo banco 'correr para ter 0 contrato pronto a tempo'." (Dantas, 1998). financeiro do grupo, cujas principais instituições eram o Meridional, banco de varejo, e o Bozano, último desse gênero totalmente nacional. Com a aquisição do Banespa, tornou-se o terceiro por ativos e o maior estrangeiro no País à época. Simonsen, de investimentos, Central Hispano (BSCH) 
do Bandeirantes, controlado pela CGD, e o Itaú adquiriu o controle do Sudameris, em função da reestruturação da italiana BCI, além de outros episódios mais recentes, como a aquisição da subsidiária do BBV pelo Bradesco, que definem uma fase de reversão parcial da abertura bancária.

\section{3_ O discurso dos banqueiros e seus objetivos}

Não é simples esclarecer que políticas os bancos estrangeiros pretendiam implementar no varejo bancário brasileiro, como pretendiam atuar. As entrevistas são pouco eficientes para esclarecer as motivações reais de cada banco. Além de ser necessário que o entrevistado conheça de fato os objetivos e planos de médio e de longo prazo da matriz, é preciso que esteja disposto a revelá-los com clareza, o que coloca para o entrevistador o desafio de separar as declarações genéricas e de propaganda daquilo que expressa de fato o ponto de vista do banco. As entrevistas tendem a se concentrar em aspectos mais gerais e conceituais, de grande relevância para a análise e para o debate público, mas insuficientes para esclarecer de modo preciso as motivações e as estratégias.

Optou-se por utilizar aqui as quatro entrevistas realizadas no curso da pesquisa
"Desnacionalização do setor bancário e financiamento da empresa nacional", publicada como texto de discussão pelo IPEA (Studart, Alves Jr. e Carvalho, 2002). Foram selecionados apenas profissionais que tivessem conhecimento amplo das estratégias do banco em que atuam e, ao mesmo tempo, com os quais fosse possível ter certeza de que a conversa seria realizada com franqueza. Foram entrevistados quatro profissionais com esse perfil, entre agosto e novembro de 2000, ligados a quatro dos bancos estrangeiros que mais ampliaram sua presença no Brasil nos anos anteriores. Dois eram diretores e dois eram gerentes regionais. Os quatro foram informados do propósito da entrevista e não sabiam quem eram os outros entrevistados. Três deles pediram sigilo completo, inclusive em relação ao nome dos bancos em que trabalham. Observadas essas restrições, o resultado das entrevistas pode ser considerado bastante esclarecedor. $^{41}$

Outro caminho seria a análise de documentos oficiais dos bancos, como apresentação de resultados e informações a mercados, mas que teriam pouca relevância por se tratar de instituições pouco ou nada interessadas em captar recursos no mercado de capitais brasileiro. Restou a análise das declarações públicas de seus diretores e porta-vozes, em que o banco procura justificar suas iniciativas e explicar co-

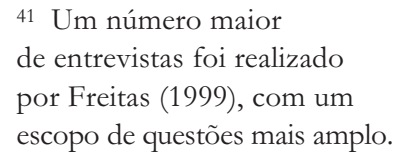


mo pretende implementá-las com êxito. Parte-se da expectativa de que, nessas declarações públicas, além de apresentar o "discurso oficial", de propaganda, os banqueiros (ou seus porta-vozes) oferecerão indicações importantes sobre seus reais objetivos, por indicações implícitas ou pela omissão de temas e questões com que não queiram assumir compromissos.

As matérias da imprensa aqui comentadas reúnem declarações públicas de diretores e de assessores de diretoria de bancos estrangeiros que atuam no mercado brasileiro, tanto de recém-ingressados quanto de alguns com presença antiga. Foram selecionadas matérias referentes ao setor de varejo, inclusive aquelas em que são comentados os motivos de alguns desses bancos para não desenvolverem estratégias agressivas na área. O levantamento não foi sistemático e pautou-se pela referência às questões apontadas na introdução do trabalho.

\section{1_As entrevistas}

Entre os pontos de maior interesse nas entrevistas realizadas, salienta-se a afirmação de que os bancos estrangeiros pretendiam atuar no mercado brasileiro para explorá-lo como ele era; estava ausente o propósito de contestar as formas de concorrência vigentes. Entre outros motivos para isso, os bancos estrangeiros percebi- am que não tinham a mesma eficiência operacional dos grandes bancos privados nacionais. A estratégia decisiva para crescer, portanto, era a compra de outros bancos e a ocupação de espaços que, segundo esperavam à época, seriam abertos principalmente pela redução da área comercial dos dois grandes bancos públicos federais - o Banco do Brasil (BB) e a Caixa Econômica Federal (CEF).

Sobre os objetivos da entrada no mercado brasileiro, apontou-se como motivação a estratégia de acompanhar as empresas dos países de origem que vinham expandindo atividades no Brasil. Um dos entrevistados destacou uma estratégia defensiva: o interesse dos bancos de ganhar volume para não serem comprados no exterior. Isso que explicaria o pouco interesse dos bancos do EUA pela América Latina, dada a viabilidade de ganhar escala no seu mercado doméstico, em contraste com a Europa. O menor interesse pelos mercados da Ásia decorreria das dificuldades de compreendê-los e pela maior grau de bancarização, enquanto no Brasil haveria grande potencial para avançar em áreas específicas, como previdência privada e habitação.

Para os quatro entrevistados, os resultados negativos nas carteiras comerciais nos primeiros anos mostraram aos bancos estrangeiros as dificuldades para atuar no 
crédito de varejo brasileiro. O custo elevado de tomar clientes da concorrência e de tirar profissionais dos bancos brasileiros, além das dificuldades para diferenciar produtos, foi uma constatação comum.

Do ponto de vista da eficiência operacional, as opiniões convergiram quanto à inexistência de vantagens dos estrangeiros. Um dos entrevistados enfatizou que Bradesco e Itaú tinham melhor qualificação para operar no varejo, pois possuíam melhores sistemas operacionais e de controle e maior agilidade para criar outros produtos, enquanto os estrangeiros reproduziam no Brasil os controles mais rígidos empregados pelas matrizes nos mercados de origem. ${ }^{42}$ Outro entrevistado apontou a redução da alçada dos gerentes em relação ao que ocorria antes da compra do banco pelo novo controlador estrangeiro, o que gera maior dificuldade para atendimento às demandas específicas dos clientes. ${ }^{43}$

Ficou claro em todas as entrevistas que a disputa por meio de preço, no crédito ou em serviços, não seria a principal forma de concorrência dos estrangeiros. Dois deles, entretanto, não tinham certeza de que essa orientação não poderia mudar no futuro. Um deles destacou a decisão dos estrangeiros de não fazer "guerra de preços" no cheque especial para pessoa física, ape- sar do potencial de ampliação da base de clientes: os spreads muito altos geravam nessa linha cerca de metade da receita com pessoas físicas, apesar de a inadimplência atingir de 20 a 25\% do total, e os bancos estrangeiros preferiram seguir os juros dos nacionais.

Os entrevistados concordaram que a principal arma da concorrência era o volume operado, por meio de aumento dos limites de endividamento e principalmente pelas aquisições e fusões para ganhar escala. Um deles destacou com muita ênfase a relevância para os estrangeiros de comprar o Banespa e, no futuro, tentar comprar o Unibanco, além de ocupar espaços deixados pelo BB e pela CEF. O Bradesco e o Itaú são vistos por todos como concorrentes muito difíceis.

\subsection{Declarações públicas}

As declarações selecionadas representam um segundo nível do discurso dos agentes em que motivos e estratégias de ingresso dos bancos estrangeiros pode ser investigada. Essa investigação teve como ponto de partida a caracterização de duas estratégias discerníveis após a liberalização do acesso ao mercado brasileiro: uma postura de cautela em relação à entrada ou expansão no varejo - Citibank, Boston, Chase, J. P. Morgan; e a entrada

\footnotetext{
${ }_{42}$ Como exemplo, citou

a prática de alguns

estrangeiros de colocar um diretor de área de controle ou de planejamento na equipe que elabora novos produtos, seguindo-se a necessidade de aprovação em diferentes instâncias.

43 Para um dos entrevistados, essas dificuldades de acompanhar a maior agilidade dos nacionais seria um dos determinantes das pressões dos estrangeiros pelo enrijecimento das normas de controle de todo o sistema como um todo, ou seja, enquadrar o Bradesco nos mesmos níveis de restrições impostos pelas matrizes aos bancos estrangeiros.
} 
agressiva no varejo, com investimentos de vulto - Santander, ABN-Amro, BBVA e HSBC, todos europeus. O Lloyds representava um caso peculiar de combinação entre as duas estratégias. O primeiro grupo reúne bancos de origem norteamericana, com longa presença no Brasil e tradição no financiamento do comércio exterior e em operações típicas de banco de investimento. Alguns já haviam realizado tentativas de ampliar a atividade de varejo a partir da reduzida rede de agências que eram autorizados a manter, sem resultados claramente satisfatórios, tendo havido bruscas reversões dessa estratégia. Sem descartar uma decisão diferente no futuro, o argumento básico para a cautela foi de que o custo de aquisição de redes amplas ficara muito alto, em comparação com a alternativa de crescer "organicamente", pela expansão progressiva da rede própria. Ao mesmo tempo, enfatiza- va-se a possibilidade de aprofundar a atuação conquanto bancos de investimento.

O comportamento do Citibank em 1997 foi emblemático da estratégia de manter-se posicionado no atacado enquanto apenas estudava as possibilidades do varejo. ${ }^{44}$ Dois anos depois, o banco reiterava sua disposição de concorrer em todas as áreas, inclusive no varejo e em camadas de renda mais baixa; entretanto só anunciou metas na área de administração de recursos. ${ }^{45}$ Em meados de 2000, ao comentar as dificuldades encontradas pelos estrangeiros no Brasil, Alcides Amaral ainda defendia que o teste decisivo é "crescer no varejo, em que se testa de fato a eficiência da rede e do pessoal", com a ressalva de que os nacionais deverão manter a liderança na área, "como em toda parte do mundo".

O BankBoston anunciou com clareza que não pretendia comprar concorrentes por não precisar de marca no País e
44 Em 1995, seu

diretor-presidente no Brasil, Roberto do Valle, destacava, como áreas de expansão, o mercado de capitais e as operações de fusão, de aquisição e de reestruturação de empresas, embora tenha sublinhado as boas perspectivas do crédito às pessoas físicas (Conjuntura Econômica, junho de 1995, p. 42). Em 1997, diante da entrada de outros estrangeiros, dizia que estava mantida a meta de aumentar negócios no varejo e que não descartava a compra de concorrentes, desde que surgisse algo "com bom preço", e que pretendia aumentar a rede de agências "modulares" (GM, 9/12/97, p. B3). Meses depois, Valle afirmou que os anos seguintes seriam "duros para a área de varejo dos bancos" e confirmou que o Citibank mantinha planos de expansão no Brasil (GM, 29/7/1998, p. B6). Contudo, com dúvidas sobre se esse crescimento seria por aumento de uso da capacidade instalada ou por fusões e aquisições, decidira esperar, pois "os preços tendem a cair" e o Citibank sob a pressão de perda de espaço no mercado de origem. 45 Área na qual pretendia ultrapassar Bradesco e Itaú até 2004, com a possibilidade de "azeitar a distribuição pela internet", o que seria mais barato que ampliar a rede de agências (GM, 1\%/9/1999, p. B3). 
pelo inconveniente de enfrentar superposição de agências, além de não ter de fato interesse em entrar no varejo "massificado". O foco de atuação do banco permaneceu no segmento de clientes com renda mensal a partir de R \$ 4 mil, estimado em 1,5 milhão de pessoas, das quais o Boston queria atrair 10\%. ${ }^{46}$ O J. P. Morgan definiu orientação semelhante, ainda mais focada nas atividades de atacado. ${ }^{47}$

A estratégia do Lloyds foi outra, ao optar pela compra da Losango, uma das maiores financeiras na área de crédito pessoal, com R $\$ 1,3$ bilhão de ativos; evitando "bater de frente" com os grandes bancos de varejo, o Lloyds decidiu atuar sem rede de agências, explorando a tecnologia, cada vez mais barata. ${ }^{48}$ Para o vice-presidente do banco no País, seria praticamente impossível para instituições financeiras estrangeiras atuar no mercado brasileiro de varejo típico, em razão da concentração e das dificuldades culturais. ${ }^{49}$ Argumento semelhante foi apontado pelo presidente do Citibank no Brasil. ${ }^{50}$

No caso do segundo grupo de bancos, a entrada agressiva no varejo foi a estratégia para ganhar espaço no Brasil. ${ }^{51} \mathrm{Tal}$ estratégia, como foi enfatizado pelos dirigentes, combinava-se de forma não exclu-

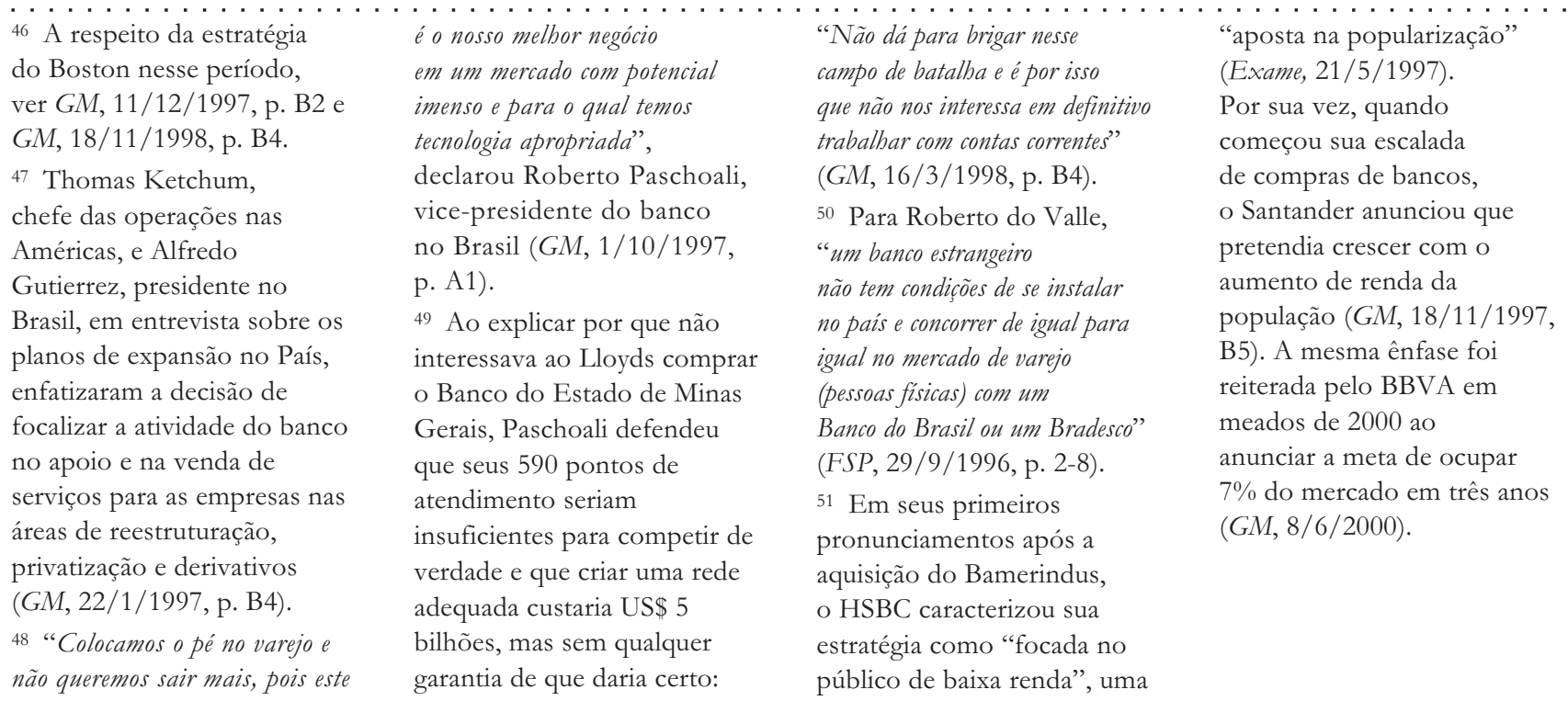


dente com a atuação prévia focada na área de "atacado". ${ }^{52}$ Um traço comum aos grandes bancos estrangeiros que optaram por esse caminho é a ausência de referências a estratégias de concorrência baseadas em redução de juros e de preços de serviços ou em aumento da oferta de crédito. $\mathrm{O}$ máximo que se encontra é a promessa de procurar se diferenciar dos concorrentes "pela qualidade e preço justo dos serviços prestados ao cliente". ${ }^{53} \mathrm{O}$ comportamento da demanda de serviços bancários pelo público, caracterizada como assimetria de informação, está presente no cálculo empresarial e contribui para a ausência dessa forma concorrencial. ${ }^{54}$

Pressionados pelos questionamentos sobre as expectativas frustradas de queda de preços e de ampliação do acesso ao crédito, os diretores dos bancos estrangeiros apresentaram explicações distintas, variando da nova gestão de receitas de tari fas $^{55}$ à responsabilização do governo e da legislação, como fez o HSBC. ${ }^{56}$ Uma das

$\begin{array}{ll}52 \text { Em meados de 1999, por } & \text { de comprar o Real, o } \\ \text { exemplo, o BBV anunciou com } & \text { ABN-Amro sublinhava o } \\ \text { destaque a inauguração de área } & \text { interesse por project finance } \\ \text { de estruturação de emissão de } & \text { e por privatizações }(G M, \\ \text { dívidas, apoiando empresas de } & \text { 25/11/1997). No fim de 2000, } \\ \text { telefonia compradas pelas } & \text { passada a euforia inicial da } \\ \text { multinacionais espanholas, e } & \text { entrada no varejo, os } \\ \text { declarou o objetivo de ser líder } & \text { estrangeiros davam sinais de } \\ \text { no setor (GM, 21/6/1999, } & \text { interesse crescente pela emissão } \\ \text { p. B1). Dois meses depois de } & \text { de papéis de empresas no } \\ \text { comprar o Excel Econômico, a } & \text { mercado de capitais doméstico, } \\ \text { diretoria do BBVA delineou um } & \text { dominado pelos bancos } \\ \text { perfil "de atacado e varejo, } & \text { nacionais - BB, Bradesco, Itaú e } \\ \text { semelhante ao Bradesco depois } & \text { Unibanco. Os estrangeiros } \\ \text { da compra do BCN" (GM, } & \text { anunciaram também a estratégia } \\ \text { 26/10/1998, p. B3). O } & \text { de disputar espaço na } \\ \text { Santander anunciou o mesmo } & \text { "originação", pela desvantagem } \\ \text { objetivo de alcançar a liderança } & \text { na distribuição decorrente da } \\ \text { também na área de atacado em } & \text { rede menor, e acrescentaram } \\ \text { comentários de seus diretores } & \text { que o mercado brasileiro } \\ \text { sobre a compra do Meridional e } & \text { oferecia o atrativo de "pagar } \\ \text { do Bozzano Simonsen }(G M, & \text { comissões maiores" } \\ 4 / 4 / 2000, \text { p. B2). Anos antes } & \text { (GM, 8/10/2000, p. B1). } \\ \end{array}$
53 Conforme declararam
diretores do BBV ao expor
seus planos para ganhar
mercado no Brasil, mas sem
dar detalhes sobre o
significado de "preço justo"
(GM, 26/10/1998, p. B3).
54 O presidente do ABN, Fábio
Barbosa, foi bem explícito ao
declarar que o foco inicial do
seu banco, depois de comprar o
Real, era melhorar o
atendimento, visto que a
qualidade dos serviços é o
segundo fator na escolha do
banco pelo cliente e o preço
vem só em terceiro lugar
(GM, 26/7/1999, p. B1).
55 Para Alex Zornig,
vice-presidente de Finanças do
BankBoston, a concorrência fez que algumas tarifas caíssem, cultura de cobrar por tudo (GM, 26/7/1999, p. B1).
56 O HSBC preferiu culpar a legislação brasileira. Para Michael Geoghegan: "Os consumidores não estão tendo acesso a juros mais baixos em empréstimos bancários [...] porque os bancos ainda têm custos fixos muito altos no país". Os obstáculos apontados por ele para a queda dos juros e a persistência dos custos altos incluem a dificuldade de recuperação de créditos, a legislação trabalhista velha, a jornada de seis horas de trabalho dos bancários, o horário rígido de funcionamento dos bancos e os compulsórios altos (FSP, 8/8/2000, p. B9). mas os estrangeiros trouxeram a 
poucas referências à competição em preços e uma possível queda dos juros veio do presidente do Citibank, justamente um dos bancos que optaram por não investir agressivamente no varejo. ${ }^{57}$

A análise desse conjunto de declarações aponta no sentido de que a estratégia dos bancos estrangeiros para ganhar espaço no mercado bancário brasileiro estaria desde seu início baseada em: tamanho da rede; qualidade do atendimento e diferenciação de produtos; disputa por tomadores de crédito sem ampliação agressiva da oferta e sem disputas por meio de preços. Um dos casos mais acabados e representativos dessa estratégia - de resto bastante assimilável à estrutura concorrencial preexistente - seria o do HSBC. ${ }^{58}$ Depois da entrada do
57 Segundo o presidente do Citi no Brasil, Roberto do Valle, na citada apresentação de seu substituto, "a guerra de preços já começou e está mais acelerada do que o previsto" (GM, 29/7/1998, p. B6), e os próximos dois anos seriam duros para a área de varejo bancário porque "a rentabilidade vai cair, junto com as taxas de juros cobradas do consumidor, devido ao aumento da concorrência imposto pelos bancos estrangeiros, e antes de 2000 os volumes não crescerão a ponto de compensar a redução das margens". Contudo, Valle teve o cuidado de enfatizar que não enxerga muito espaço para a redução dos juros, em razão dos altos custos impostos pela inadimplência, e por isso "a queda deve se contentar com dois ou três pontos percentuais ao mês", posto que "a inadimplência com pessoa física está em 5\%, ainda abaixo dos $7 \%$ de 1995 , mas muito maior do que o esperado para 1998". E concluiu informando que o Citibank cobrava entre 9 e $14 \%$ ao mês no cheque especial e que o alargamento da faixa de flutuação já refletia a busca de melhor posicionamento diante $\mathrm{da}$ concorrência, com a orientação de cobrar "menos dos clientes que oferecem maior reciprocidade e mais dos que atrasam".

58 É ilustrativa nesse sentido a longa matéria da revista Exame [21/5/1997, p. 54-61] sobre a entrada do HSBC, tratada então como um marco na história financeira do Brasil. Segundo os diretores do banco entrevistados pela revista, o meio para crescer no Brasil seria a popularização, o atendimento do público de baixa renda, mas não apareceu uma palavra sequer sobre juros, preços de serviços ou maior oferta de crédito. $\mathrm{O}$ HSBC pretendia ganhar espaço "sendo ele mesmo".

Para seus diretores, a maioria dos bancos no Brasil segue "a escola bancária americana, centrada no marketing e na venda de produtos. O que conta é o número de produtos que o cliente compra, mesmo que muitas vezes ele nem sequer esteja precisando deles", como seguros e capitalização, "empurrados pelos gerentes em contrapartida a uma operação de crédito". O HSBC queria seguir "modelo desenvolvido por outra escola", da qual ele "talvez seja o melhor representante no mundo": o desenvolvimento de relação de longo prazo com o cliente, baseada em "vender o que ele quer". A revista dá como exemplo o Oriente Médio, com "as relações do banco com o cliente no meio de deserto": conversar, conhecer - um "banco de

relacionamento". O HSBC é apresentado como um banco conhecido pela variedade de produtos. Contudo, o que representaria isto no Brasil estava sob sigilo (a "única pista" era o cartão de crédito com pontuação por lealdade), mas já estava desenhada uma ofensiva publicitária, para "vincular peças publicitárias aos produtos que o banco pretende lançar. Alguns virão do exterior e serão adaptados às condições brasileiras. Outros serão desenvolvidos aqui mesmo no Brasil". 
HSBC, do Santander e do BBV, o problema do tamanho mínimo da rede ganhou maior destaque. O ABN-Amro justificou o preço pago pelo Banco Real com o argumento de que sua rede tinha o tamanho mínimo requerido para um banco de varejo no Brasil, bem como pela necessidade de aumentar o total de ativos e para competir em custos. ${ }^{59}$ Para os que optaram pelo varejo bancário, a estratégia de crescimento por aquisição estava relacionada com a escala de operações. O relatório especial da Gazeta Mercantil (31/8/2000) registrava que "os estrangeiros têm crescido rápido, mas as fatias individuais conseguidas ainda são insuficientes para que possam ser competitivos e rentáveis. Precisa- riam ter 2 a $3 \%$ para garantir presença, e só ABN, HSBC e Santander possuem esse percentual dos ativos totais". ${ }^{0}$ As dificuldades a essa altura já decorriam de Bradesco, Itaú e Unibanco se defenderem bem e os estrangeiros ficarem obrigados a "ampliar o volume de crédito em ambiente cada vez mais competitivo".

Aspecto pouco esclarecido pelas declarações foi a ocorrência de aprimoramentos nos procedimentos internos e sua efetiva capacidade de induzir reduções de custo. ${ }^{61} \mathrm{O}$ impacto da modernização tecnológica sobre os custos parecia mais previsível, inclusive por representar um novo espaço de concorrência, associado a escala e outros requisitos. ${ }^{62}$

\begin{tabular}{|c|c|c|c|}
\hline $\begin{array}{l}59 \text { Um aspecto a se } \\
\text { materializar não de imediato: } \\
\text { "Um parâmetro que ainda } \\
\text { não existe no Brasil, onde o } \\
\text { consumidor paga tudo. } \\
\text { Mas vai chegar o momento } \\
\text { em que essa competição, já } \\
\text { vivenciada no mercado } \\
\text { europeu, chegará aqui e o } \\
\text { consumidor se recusará a } \\
\text { pagar tudo. Isso vai acontecer } \\
\text { mais rápido do que se espera" } \\
\text { (GM, 16/12/1998, p. B4). } \\
60 \text { Em meados de 2000, } \\
\text { a Gazeta Mercantil apontava } \\
\text { o plano do BBVA de ter sua } \\
\text { participação ampliada de } 1,6\end{array}$ & $\begin{array}{l}\text { para } 7 \% \text { no mercado em três } \\
\text { anos, posto que a } \\
\text { "sobrevivência" seria viável } \\
\text { apenas para quem tivesse de } \\
7 \% \text { a } 10 \% \text { do mercado, e a } \\
\text { principal estratégia para } \\
\text { crescer era comprar } \\
\text { instituições. O banco pretende } \\
\text { ampliar linhas para pequenas e } \\
\text { médias empresas para crescer, } \\
\text { "mas isto depende de } \\
\text { mudanças na política } \\
\text { econômica e de queda da taxa } \\
\text { de juros" (GM, } 8 / 6 / 2000) \text {. } \\
61 \text { Ao se apresentar ao } \\
\text { mercado brasileiro, o HSBC } \\
\text { anunciou a flexibilização da }\end{array}$ & $\begin{array}{l}\text { estrutura decisória, com } \\
\text { política de crédito baseada no } \\
\text { fluxo de caixa dos clientes, } \\
\text { sem comitês de crédito. Os } \\
\text { gerentes teriam um limite de } \\
\text { crédito e poderiam aplicar } \\
\text { como julgassem conveniente, } \\
\text { o que permitiria inadimplência } \\
\text { muito baixa, pela experiência } \\
\text { internacional do banco } \\
\text { [Exame, } 21 / 5 / 1997, \text { p. } 54-61] \text {. } \\
62 \text { O ABN-Amro apontou o } \\
\text { incremento da base } \\
\text { tecnológica como meio para } \\
\text { "oferecer serviços mais ágeis" } \\
\text { e para ampliar a base de } \\
\text { clientes }(G M, 26 / 9 / 2000,\end{array}$ & $\begin{array}{l}\text { p. B3). Para Pedro Guimarães, } \\
\text { analista do setor financeiro } \\
\text { do Bozano, Simonsen, } \\
\text { "com a utilização da internet } \\
\text { haverá redução de custos } \\
\text { dos bancos, mas também } \\
\text { haverá redução de spreads, } \\
\text { devido à concorrência. } \\
\text { Assim, só terá lucro quem } \\
\text { tiver ganho com volume de } \\
\text { operações". Em razão da } \\
\text { necessidade de confiança } \\
\text { dos clientes, porém, bancos } \\
\text { grandes e tradicionais } \\
\text { "largam na frente" } \\
\text { (GM, 10/2/2000, B2). }\end{array}$ \\
\hline
\end{tabular}


Um primeiro balanço das dificuldades dos bancos estrangeiros no varejo bancário brasileiro apareceu em longa matéria da Gazeta Mercantil em 26/7/1999 (p. B1). Para Fábio Barbosa, presidente do $\mathrm{ABN}$ "esta história de que os bancos estrangeiros iriam chegar aqui tirando coelhos da cartola é um mito". Os mais otimistas destacavam que os bancos estrangeiros estavam avançando lentamente, respeitando problemas locais e procurando superá-los. ${ }^{63}$ As declarações confirmam a limitação dos ganhos de produtividade internos, por mudanças de métodos e avanços tecnológicos, uma vez que os bancos nacionais também eram capazes de inovar e avançar nessa e em outras direções. Em 1997 a imprensa já comentava a reação do Bradesco, o que incluía a diversificação do atendimento, a procura de nichos específicos, a associação com empresas estrangeiras em áreas como previdência e outras, a ampliação da rede, o corte de custos e o aumento da eficiência, medida por receitas e depósitos por funcionário (GM,15/10/1997, p. B 16). A contra-ofensiva tornou-se evidente com a recompra de bancos antes adquiridos por estrangeiros, comentada na Folha de S. Paulo (9/7/2000, p. B8) sob o título de "Bancos nacionais recuperam terreno". Segundo Eri- velto Rodrigues, analista do setor bancário, na mesma matéria, "a vantagem dos estrangeiros era a captação mais barata, mas ela não foi suficiente para fazer a diferença frente aos nacionais", embora levando em conta que os bancos estrangeiros teriam adiado seus planos para se beneficiar das altas taxas de juros da dívida pública.

O caso mais destacado de reversão das expectativas foi sem dúvida o HSBC. "O segundo maior banco global não assumiu a liderança do mercado nacional, como se temia, nem mudou o padrão local de concorrência na varejo bancário, como se previa", conclui a matéria do Valor Econômico, intitulada "Os tropeços do HSBC na maratona brasileira" (10-12/11/2000, p. A12). Segundo o jornal, o HSBC pisou no freio, caiu no ranking, mas não perdeu dinheiro: ganhou muito com aplicação em títulos, de onde veio a maior parte do seu lucro, graças à boa posição de liquidez. $\mathrm{O}$ banco enfrentou "problemas graves com a inadequação da rede de agências e atraso tecnológico, dificuldades com o treinamento de funcionários e fraudes internas, além de que os graves problemas macroeconômicos no exterior (crise na Ásia e na Rússia) teriam estimulado o conservadorismo do banco no Brasil".
63 Para Tom Camargo, diretor de comunicação e marketing do hsbc, seu banco não promoveu mudanças drásticas em razão dos "engessamentos" do mercado brasileiro compulsórios, exigibilidades, cunha fiscal e excesso de leis - e preferiu então investir e empreender "uma cruzada suave e paciente" para ajudar a eliminá-los. 
O tom de decepção contrasta fortemente com a quase euforia cultivada quando o HSBC comprou o Bamerindus. ${ }^{64}$ Dois anos depois, as dificuldades do HSBC para atingir seus objetivos no Brasil passam a ser justificadas por problemas locais. ${ }^{65}$ Ainda assim, o HSBC não perdeu dinheiro no Brasil graças aos ganhos propiciados pelas altas taxas de juros e pela desvalorização cambial. Ao comentar os excelentes resultados da filial brasileira no primeiro semestre de 1999, Douglas Flint, principal executivo financeiro do grupo HSBC, destacou que

os ganhos no Brasil vieram mais das altas taxas de juros do que das operações cambiais. A postura conservadora do banco no mercado brasileiro de crédito levou a uma posição de alta liquidez, que, por sua vez, gerou elevado retorno na aplicação em titulos do governo. Os juros altos contribuiram para forte expansão dos fundos de investimentos, que cres-ceram de $\mathrm{R} \$ 4,5$ bilhões para $R \$ 7$ bilhões no primeiro semestre. [...] O custo dos empréstimos ruins e duvidosos permaneceu baixo e bem coberto pelas margens das operações de crédito (GM, 3/8/1999).

Por fim, é interessante destacar a dificuldade dos grandes bancos brasileiros de assumir uma posição pública definida. Enquanto envolvia unidades sem potencial competitivo ou um banco em crise com risco de contágio, o crescimento da participação estrangeira não provocou reações. O presidente da Federação Nacional dos Bancos Brasileiros (Febraban), entretanto, posicionou-se preventivamente, defendendo um sistema financeiro preponderantemente nacional e aventando que se esta-
64 "Abertura chega ao varejo bancário", comemorou a Gazeta Mercantil (27/3/1997, p. B2), enfatizando que "o HSBC é talvez o maior varejista do mundo, atua no varejo em mais de setenta países, não é como outros que são varejistas apenas no mercado de origem", é um "gigante com fontes quase ilimitadas de recursos, tecnologia de ponta de varejo e uma rede de captação pronta, formada e treinada, tanto do ponto de vista físico como humano". O texto comemora o que teria sido "uma demonstração de confiança no país e na estabilização" e destaca a redução do risco de corridas bancárias e o aumento da segurança do sistema, muito necessária nos "países com planos de estabilização baseados em âncora cambial, em que se reduz a margem de manobra do BC em

momentos de dificuldades". A posição de confiança apareceu igualmente na matéria da revista Exame (21/5/1997, p. 54-61), já comentada.

65 Segundo Michael

Geoghegan, principal executivo do banco no País: "Precisamos reduzir a taxa de juros no Brasil. Os consumidores não estão tendo acesso a juros mais baixos em empréstimos bancários [...] porque os bancos ainda têm custos fixos muito altos no país". E apontou os obstáculos: dificuldade dos bancos para recuperar créditos; legislação trabalhista velha; jornada de trabalho de seis horas dos bancários; horário rígido de funcionamento dos bancos; e compulsórios altos (FSP, 8/8/2000, p. B9). 
belecesse o teto de 30\% à participação estrangeira. ${ }^{66}$ As razões invocadas giraram em torno de três eixos. "O primeiro deles é que a condução de políticas monetárias e o controle de fluxo de capitais por parte das autoridades são, evidentemente, mais fáceis de ser feitos na medida em que essas instituições sejam nacionais, sobre as quais ela tem uma ascendência muito maior /.../". Segundo, que as políticas de crédito das subsidiárias, sendo determinadas mundialmente pela matriz, poderiam desassistir os interesses locais, regionais e a pequena e média empresa. Terceiro, devido ao mesmo tipo de diretriz centralizada de alocação de recursos e assunção de risco, poderia haver uma retração do crédito ao País, eventualmente comprometendo o financiamento do governo, da dívida pública e dos Estados.

Ao vocalizar sua visão da abertura, o empresariado bancário nacional procurou identificá-la com o interesse geral da sociedade. Talvez porque sua imagem pública dificultasse a assunção de interesses puramente particularistas, excluiu-se do debate uma das principais fontes de assimetria competitiva em favor do competidor externo: o menor custo do capital associado à profundidade dos mercados de capitais centrais e diferenciais regulatórios relativos à estruturação do capital.

\section{Notas finais}

Este artigo analisou o discurso do governo e de banqueiros estrangeiros por ocasião da abertura do setor bancário de varejo ao capital externo, na segunda metade da década de 1990. As autoridades defendiam a abertura argumentando que a maior base de capital e superioridade operacional e competitiva do capital estrangeiro tornariam o setor mais eficiente e competitivo, com os custos mais baixos sendo repassados aos tomadores de crédito e usuários de serviços bancários. Diretores e portavozes dos bancos estrangeiros que ingressaram no País, ao contrário, limitaram-se a promessa genéricas de "qualidade e preço justo", sem qualquer menção à possibilidade de atuarem de acordo com o prometido pelo governo.

A abertura e o ingresso de grandes bancos estrangeiros no mercado brasileiro não aumentaram a oferta de crédito nem reduziram os spreads bancários e os custos para os tomadores. $\mathrm{O}$ resultado reforça o que foi delineado nas entrevistas com quatro diretores e gerentes-gerais de bancos estrangeiros e que apareceu nas declarações públicas de executivos dessas instituições: os estrangeiros pretendiam disputar mercado em parte pela diferenciação de produtos, em parte pela prestação de serviços mais eficientes e pela compra de participações. Foram raras as referências a con-

\author{
66 Entrevista de Roberto \\ Setúbal, CEO do Banco \\ Itaú e presidente da Febraban \\ (Federação Brasileira dos \\ Bancos/Associação dos \\ Bancos Brasileiros, entidade \\ mais abrangente do setor \\ financeiro do País), à revista \\ Carta Capital (Drummond, \\ 1997). Como a Febraban \\ inclui bancos estrangeiros, a \\ posição não seria consensual, \\ mas presumivelmente refletia \\ a visão dominante entre os \\ grandes bancos nacionais.
}


corrência por preços ou por ampliação do acesso ao crédito. A motivação mais destacada pelos bancos estrangeiros foi a busca do mercado bancário de varejo pela perspectiva de aumento expressivo da "população bancarizada", além de atividades típicas de banco de investimento (mercado de capitais, apoio a fusões e incorporações de empresas, engenharias financeiras, privatização, comércio exterior), que sempre atraíram as filiais dos bancos estrangeiros.

A conclusão central do trabalho é que, de um lado, o apego oficial ao argumento pró-abertura escondeu o interesse efetivo de favorecer a estabilidade do setor bancário e da economia; e, por outro lado, o capital privado estrangeiro procurou de fato explorar o mercado bancário brasileiro sob as condições preexistentes, sem alterá-las. Além disso, aproveitando-se da instabilidade macroeconômica do período e da predisposição oficial em abrir o mercado bancário brasileiro, os bancos estrangeiros impuseram ao BCB sua estratégia preferencial de expansão - a aquisição de instituições nacionais privadas de porte grande e médio -, frustrando parcialmente o objetivo do BCB de condicionar a entrada dos bancos estrangeiros à aquisição de bancos estaduais federalizados. 


\section{Referências bibliográficas}

\author{
ABDULMACIH, Verenice P. G. \\ A Reforma de 1988: bancos \\ múltiplos e concentração bancária \\ no Brasil. 2000. Dissertação \\ (Mestrado em Economia Política) \\ - PUCSP, São Paulo, 2000. \\ BAER, Mônica. A internacionalização \\ financeira no Brasil. Petrópolis: \\ Vozes, 1986.
}

BALARIN, Raquel; RODRIGUES Azelma. Malan: prioridade é vender estaduais. Gazeta Mercantil, 20 out. 1997. Caderno Finanças e Mercados.

BCB (Banco Central do Brasil). Juros e spread bancário no Brasil. Brasília, 1999.

BCB (Banco Central do Brasil). Relatório de Economia Bancária e Crédito. Brasília, 2005.

BELAISCH, Agnés. Do Brazilian Banks Compete? Washington: International Monetary Fund, 2003. (Working Paper, 3/113).

CALDERÓN, Alvaro; CASILDA, Ramón. La Estrategia de los Bancos Españoles en América Latina. Santiago, Revista de la Cepal, n. 70, p. 71-89, 2000.
CARVALHO, Carlos E. Liquidez e choques antiinflacionários. In: BATISTA Jr., P. N. BELLUZZO, L. G. M. (Orgs.). A luta pela sobrevivência da moeda nacional. São Paulo: Paz e Terra, 1992. p. 126-203.

\section{CARVALHO, Carlos E. Crise}

bancária questiona a independência do BCB. São Paulo, Conselho Regional de Economia. Economia em Perspectiva, p. 2-3, jan. 1996.

CARVALHO, Carlos E.;

OLIVEIRA, Giuliano.

Fragilização de grandes bancos no início do Plano Real. Belo Horizonte, UFMG, Nova Economia, v. 12, n. 1, p. 69-84, 2002.

CARVAlHO, Maria. C. As faces da globalização no Brasil. Gazeta Mercantil, São Paulo, 2 jul. 1997. Caderno Finanças e Mercados.

CARVALHO, Maria. C. Estrangeiros dominam 16,6\% do mercado brasileiro. Gazeta Mercantil, São Paulo, 22 set. 1997. Caderno Finanças e Mercados.

CARVALHO, M. C; ALVES, F.; BORTOT, I. J. Bancos entram no Brasil por atalho do BC. Gažeta Mercantil, São Paulo, 10-12 maio 1996. p A-1 e B-1.
CECON-UNICAMP. Dinheiro

Curto. Bancos estrangeiros

são mais seletivos nos empréstimos. Carta Capital, São Paulo, 13 set. 2000.

DANTAS, Fernando. Demonstrações de confiança. Gazeta Mercantil, São Paulo 25 nov. 1998. Relatório Brasil-Holanda.

DIEESE. Departamento Intersindical de Estatística e Estudos Socioeconômicos. Desempenho dos Bancos Privados em 1994. Estudos Setoriais DIEESE, Rio de Janeiro, 1995.

DRUMMOND, Carlos. Tremor na Cordilheira. Carta Capital, 9 jul. 1997. p. 27-37.

FREITAS, M.C.P. (Org.). Abertura do sistema financeiro no Brasil nos anos 90. São Paulo-Brasília: Fundap/Fapesp/ Ipea, p. 101-173, 1999

IBGE. Sistema financeiro: uma análise a partir das contas nacionais. Rio de Janeiro: IBGE, 1997. 164p.

LUCA, Léa. BBV diz como planeja ganhar mercado no Brasil. Gažta Mercantil, São Paulo, 26 out. 1998. Caderno Finanças e Mercados.
MACARINI, José P. A política bancária do regime militar: o projeto de conglomerado (1967-1973). Campinas: IE-Unicamp, 2007. (Texto para Discussão, 124).

MADI, Maria Alejandra C.; MELETI, Patricia M. F. Tendências Estruturais dos Bancos Privados no Brasil: dinâmica das relações entre bancos e empresas não financeiras (1990-94). São Paulo: Fundap/IESP, 1995. (Texto para Discussão)

MATHIESON, Donald J.; SCHINASI, Garry J. (Coord.). The role of foreign banks in emerging markets. In: International capital markets: development, prospects, and key policy issues. Washington: International Monetary Fund, Sept. 2000.

MINELLA, Ary C. Banqueiros: organização e poder político no Brasil. São Paulo: Espaço e Tempo/ANPOCS, 1988.

MORAIS, Pedro B. Foreign Banks in the Brazilian Economy in the 1980s. Departamento de Economia, PUC-RJ, Rio de Janeiro/RJ, 1990. (Texto para Discussão, 241). 
MORRIS, Felipe. Latin America's Banking Systems in the 1980s. Washington: The World Bank, 1990. (World Bank Discussion Papers).

NAKANE, M. Concorrência e spread bancário: uma revisão da evidência para o Brasil. In: BANCO CENTRAL DO BRASIL. Economia bancária e crédito - avaliação de 4 anos do projeto juros e spread bancário. v. VI, p. 58-67, 2003.

PAULA, Antônio D. de. A lucratividade do setor bancário, privado e nacional (1991-95). 2000. 173p. Dissertação (Mestrado em Economia Política), PUC/SP, São Paulo, 2000

POSSAS, Mário L. Estruturas de mercado em oligopólio. São Paulo: Hucitec, 1984.

PRADO, Maria C. R. M. Rubin quer mais bancos em países emergentes. Gazeta Mercantil, São Paulo, 23 set. 1997.

SOUZA, Rodrigo M. L.

Estrutura e determinantes do spread bancário no Brasil: uma resenha comparativa da literatura empírica. 2006. Dissertação (Mestrado em Economia) Programa de Pós-Graduação da Faculdade de Ciências Econômicas da UERJ, 2006.

STUDART, Rogério; ALVES Jr., Antônio J.; CARVALHO, Carlos E. Desnacionalização do setor bancário e financiamento das empresas: a experiência brasileira recente. Brasília, IPEA, 2002. (Texto para Discussão, 882).
TEIXEIRA, Natermes G.

O sistema bancário brasileiro e suas transformaçoes frente a crise atual.

1985. Tese (Doutorado em

Economia) - IE Unicamp,

Campinas, 1985.

VELLOSO, Eliane. BC analisa doze pedidos de bancos estrangeiros. Gazeta Mercantil, São Paulo, 12-14 set. 1997.

Caderno Finanças e Mercados.

VELLOSO, Eliane. BC limitará capital externo no varejo.

Gazeta Mercantil, São Paulo, 25 nov. 1997. Caderno Finanças e Mercados.

VIDOTTO, Carlos A.

Protecionismo e abertura no setor bancário brasileiro: o sentido da metamorfose regulatória. Pesquisa e Debate, São Paulo, v. 10, n. 1, p. 77-102, 1999.

VIDOTTO, Carlos A. O Proer no centro da reestruturação bancária dos anos noventa. In: VI

CONGRESSO BRASILEIRO DE HISTÓRIA ECONÔMICA $/ 7^{\mathrm{a}}$ CONFERÊNCIA

INTERNACIONAL DE HISTÓRIA DE EMPRESAS.

Anais... Conservatória:

ABPHE, 2005.

WORLD BANK. Brazil.

Selected Issues of the Financial Sector. Washington, Mar. 1990. (Report 7725).

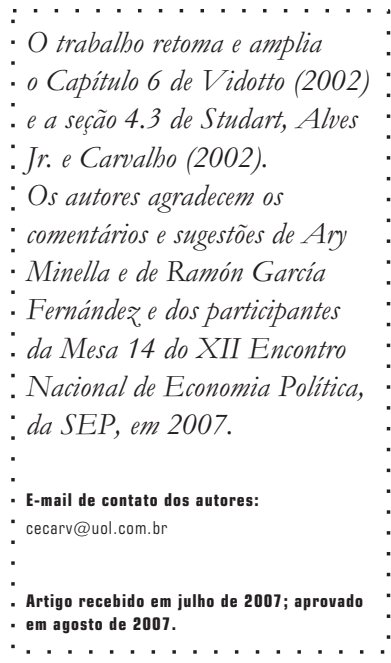

